$\triangle$ CTA $\mathbb{N}$ EOPHILOLOGICA

UDK: 821.111(73).09Twain M.:

DOI: 10.4312/an.52.1-2.141-152

[070:342.151.3(73=163.6)]

\title{
Ideological Influences on the Reception of Mark Twain among Slovenians across the Atlantic
}

Janko Trupej

\section{ABSTRACT}

The article discusses the reception of Mark Twain and his works in serial publications by Slovenian immigrants in the United States of America. The analysis encompassed writings published in newspapers and magazines with different ideological orientations, from the beginning of the 20th century to mid-century. The article compares Twain's reception in left-wing and right-wing publications and furthermore discusses the extent to which the reception was affected by the contemporary political situation in the United States.

Key words: Mark Twain, reception, serial publications, ideology, Slovenians in the United States of America, American literature 


\section{INTRODUCTION}

For centuries, literary studies have focused primarily on discussing authors and their works; only in the second part of the $20^{\text {th }}$ century did interest expand to some extent; specifically, representatives of reader-response criticism began to argue that readers contributed to shaping the meaning of literary works, and therefore these scholars endeavoured to establish how readers experienced particular works of fiction (Pezdirc Bartol 195). Hans Robert Jauss asserted that readers should receive the same amount of attention as texts and their authors, since readers actively shape the 'historical life' of each literary work: when it is first published, readers compare it to other literary works, and later each new generation of readers reassesses its aesthetic value ("Literary" 7-9; cf. Estetsko 16). Literary theory thus started to focus on "the production of meanings within the reading process" (Baldick 212).

Mark Twain is one of the best-known literary figures in the United States of America. While for Edgar Allan Poe, another giant of world literature, the phrase nemo propheta in patria may be somewhat true even to the present day (Zupan 121), this never was the case with Twain. Throughout his lifetime, he was well-known, especially because of his travel writing, for instance the travelogues Innocents Abroad and Roughing It, which were extremely commercially successful (Messent 12). In the late $19^{\text {th }}$ century, Twain was already regarded as one of the greatest American writers of realistic fiction, along with William Dean Howells and Henry James (Krieg 407). In the first half of the $20^{\text {th }}$ century, some influential literary critics' opinions about Twain's oeuvre were somewhat more reserved; for instance, in the influential monograph The Ordeal of Mark Twain, Van Wyck Brooks discussed the reasons for Twain's supposed artistic shortcomings, while Malcolm Cowley did not consider Twain to be as great a writer as Thomas Mann or Leo Tolstoy (180). This changed later, with Twain's reputation largely resting on Adventures of Huckleberry Finn; there are even claims of a 'hypercanonization' of this novel (Arac vii), which is widely considered as one of the great American novels, along with works like The Scarlet Letter, Moby Dick, The Great Gatsby, and The Grapes of Wrath. ${ }^{1}$

The present paper will discuss the historical reception of Mark Twain and his works by Slovenians on the other side of the Atlantic, by analysing writing

1 For instance, Jonathan Culler describes the novel as a "work which does as much as any other to define Americanness" (53), while Sandra M. Gustafson claims that Huckleberry Finn "represents the pre-political, natural innocence and camaraderie of Americans reclaimed from the anti-democratic corruptions of slavery" (34). The protagonist's deliberation whether to help return the runaway slave Jim to his owner or to help him escape, which ends with Huckleberry Finn opting for the latter-despite thinking he would go to hell because of it - was even described as "arguably the most moral moment in American literature” by Robert Paul Lamb (482). See Grosman (157-62) for an overview of the novel's reception in the United States. 
about Twain in Slovenian immigrant print in the United States. The analysis encompassed Slovenian serial publications from the beginning of the $20^{\text {th }}$ century, when a few Slovenian newspapers were already being published in the United States, to the mid-1950s; by that time many Slovenian newspapers had ceased publication. It will thus be established how several generations of Slovenian readers in the United States, with diverse ideological orientations, perceived Twain. Furthermore, the paper will shed light on the extent to which this author's reception was influenced by the contemporary socio-political situation. ${ }^{2}$

\section{ANALYSIS OF THE CORPUS OF SERIAL PUBLICATIONS}

News articles about Twain were published in both the oldest right-wing and leftwing Slovenian newspapers in the United States: Amerikanski Slovenec and Glas naroda, respectively. Before his death on 21 April 1910, the name 'Mark Twain' had appeared in 13 issues of the former and 42 issues of the latter serial publication. Amerikanski Slovenec reported on events in Twain's life, for instance the lavish celebration of his $70^{\text {th }}$ birthday $(5 / 1 / 1906,4),{ }^{3}$ his visit to Europe $(26 / 7 / 1907,7),{ }^{4}$ etc. Glas naroda also reported on his travels (9/6/1903, 1; 7/11/1903, 2; 29/6/1904, 2; 21/6/1907, 1), ${ }^{5}$ his birthday celebrations $(7 / 12 / 1905,1 ; 2 / 12 / 1908,1),{ }^{6}$ his visit to the White House $(29 / 11 / 1905,1),{ }^{7}$ etc. Both newspapers also ran articles on Twain's death. In Amerikanski Slovenec $(29 / 4 / 1910,1)$, there is a brief account of his life; the article concludes by asserting that Twain laboured intensively after he had to declare bankruptcy and was a millionaire at the time of his death. ${ }^{8}$ An article in Glas naroda $(22 / 4 / 1910,1)$ recounts some of the major events in Twain's life and lauds him as America's greatest humorist, ${ }^{9}$ while another article in the same newspaper $(25 / 4 / 1910,1)$ notes that, despite being world-renowned as a

2 The corpus for the analysis encompassed almost 1,000 individual issues of serial publications, i.e. all the serial publications published by Slovenian immigrants in the United States available on the portal Digital Library of Slovenia, which mentioned Twain or some of his major works.

3 N.N. "Mark Twain.” Amerikanski Slovenec, 5/1/1906, p. 4.

$4 \quad$ N.N. "Mark Twain." Amerikanski Slovenec, 26/7/1907, p. 7.

$5 \quad$ N.N. "Mark Twain se [sic] naveličal Amerike." Glas naroda, 9/6/1903, p. 1.| N.N. "Evropejske in druge vesti." Glas naroda, 7/11/1903, p. 2. | N.N. "Napulj." Glas naroda, 29/6/1904, p. 2. | N.N. "Mark Twain v Londonu." Glas naroda, 21/6/1907, p. 1.

6 N.N. "Mark Twainov rojstni dan." Glas naroda, 7/12/1905, p. 1. | N.N. "Mark Twain star 73 let." Glas naroda, 2/12/1908, 1 .

$7 \quad$ N.N. "Mark Twain, predsednikov gost." Glas naroda, 29/11/1905, p. 1

8 N.N. "Dva slavna pisatelja umrla." Amerikanski Slovenec, 29/4/1910, p. 1.

9 N.N. "Mark Twain umrl. Najboljši humorist." Glas naroda, 22/4/1910, p. 1. 
humorist, Twain also wrote a philosophical text on the true nature of humankind, entitled "What is Man?". ${ }^{10}$

In the decade after Twain's death, only a few notable articles about him were published in Slovenian serial publications in the United States. In the Catholic newspaper Glasilo K.S.K. jednote $(12 / 5 / 1915,5)$, an article describing Twain's private audience with Emperor Franz Josef in Vienna claims that the monarch was very kind and generous to the greatest American humorist- support for AustriaHungary during the Great War is clearly evident. ${ }^{11}$ An article published in Glas naroda $(16 / 10 / 1917,4)$ uses Twain's image to express a rather different sentiment. The anonymous author asserts that no man of letters has ever depicted human weakness better than Twain, and hails him as a prophetic figure because he described the circumstances that cause wars, which could also be applied to the situation leading up to World War I. The article ends on a political note, i.e. by expressly blaming the Austro-Hungarian Empire and the German Empire for the outbreak of the war. ${ }^{12}$ An article published in the progressive newspaper Enakopravnost $(30 / 7 / 1920,2)^{13}$ after the war can be perceived as criticism of Twain: it discusses the recently published monograph entitled The Ordeal of Mark Twain, in which Van Wyck Brooks argues that Twain never reached full artistic maturity because he somewhat conformed to the expectations of society-and that deep down he felt guilty for doing so.

Several articles on Twain in the inter-war period were published in more than one newspaper-even in newspapers with different ideological orientations. In one such article, first published in Glasilo K.S.K. jednote $(11 / 11 / 1925,6)$ and next year also in Glas naroda (5/11/1926, 2), Twain's life is recounted, it is asserted that Adventures of Huckleberry Finn and The Adventures of Tom Sawyer are his best works and furthermore that in some of his writings there is shrewd observation and common sense under the guise of humour and superficiality. ${ }^{14}$ Another article published in Glas naroda $(2 / 5 / 1928,2)$, Prosveta $(5 / 5 / 1928,3)$ and Amerikanski Slovenec $(9 / 5 / 1928,3)$ starts by claiming that recently published letters of Twain's reveal him "not as a light-minded optimist, as he was perceived by the average reader, but as a philosophic writer whose strongly developed sense of humour mastered his deep insight into the drama of life" ${ }^{15}$. After a description of his life and

10 N.N. "Skrivnost humorista Mark [sic] Twaina." ,25/4/1910, p. 1.

11 N.N. "Mark Twain v [sic] avdijenci pri avstrijskem cesarju." Glasilo K.S.K. jednote, 12/5/1915, p. 5.

12 N.N. "Mark Twain kot prerok." Glas naroda, 16/10/1917, p. 4.

13 N.N. "Mark Twainova žaloigra." Enakopravnost, 30/7/1920, p. 2.

14 N.N. “Dne 30. novembra, 1835 - Rojstvo Mark Twain-a.” Glasilo K.S.K. jednote, 11/11/1925, p. 6. / N.N. "Obletnice znamenitih Amerikancev." Glas naroda, 5/11/1926, 2.

15 All quotations originally in Slovenian were translated into English by the author of the present paper. 
his best known works, the claim is made that in addition to being humorist, Twain was a first-class novelist and that The Adventures of Tom Sawyer and Adventures of Huckleberry Finn are among the most beautiful examples of American literature. ${ }^{16}$ In an article published in both Enakopravnost and Glas naroda on the very same day $(18 / 12 / 1935,2)$, an author writing under the pseudonym of F.L.I.S. notes that in the United States there exists a debate about Twain's significance: some see him first and foremost as a humorist, while others find more value in his satirical writings, in which he criticized contemporary American society for its lack of tolerance and social justice. F.L.I.S. asserts that works like The Mysterious Stranger, The Gilded Age and "The Man that Corrupted Hadleyburg" reflect Twain's feeling of living in a senseless world. The article ends with a quotation from Mark Twain's Notebook. ${ }^{17}$ In the original, the passage reads as follows: "Europe for a thousand years has existed merely for the advantage of half a dozen seventh-rate families called Monarchs, and some hundreds of riffraff sarcastically called Nobles"(195).

Perhaps the most ideologically charged of all the articles about Twain ever published in Glas naroda $(2 / 12 / 1935,2)$ commemorated the $100^{\text {th }}$ anniversary of the writer's birth. Peter Zgaga ${ }^{18}$ starts by proclaiming Twain to be the greatest American humorist, who had faith in humanity and democracy, opposed war, and was a true American patriot. The article goes on to assert that Twain was against the Philippine-American War, condemned Belgian atrocities committed in the Congo, and was one of the greatest opponents of tsarist Russia. The main part of the text is devoted to Twain's prose poem "The War Prayer", which was written in 1905, but published only after the writer's death. Zgaga claims that with this masterpiece Twain condemned the hypocrisy of those who send young men to be butchered in the name of divine justice, all the while claiming to be instruments of God and placing all the blame on the opposing side. The author of the article further asserts that, during World War I, this prayer was recited by imperialists in all the participating countries, and that in 1935 it is being recited by Mussolini, who has the support of the Italian clergy. The article concludes with a Slovenian translation of the poem ${ }^{19}$.

Twain was sometimes featured in the socialist newspaper Proletarec. One such article $(17 / 4 / 1917,4)$, mentions that Twain set up a publishing house for both

16 N.N. "Mark Twain.” Glas naroda, 2/5/1928, p. 3. / F.L.I.S. "Mark Twain.” Prosveta, 5/5/1928, p. 3. / N.N. "Mark Twain." Amerikanski Slovenec, 9/5/1928, p. 3. The author is credited only in Prosveta.

17 N.N. "Stoletnica rojstva Mark [sic] Twain-a." Enakopravnost, 18/12/1935, p. 2. / N.N. "Stoletnica rojstva Mark [sic] Twaina.” Glas naroda, 18/12/1935, p. 2.

18 This was the pseudonym used by publicist Janez Trček (1891-1942), who immigrated to New York in 1912. He soon started contributing to the newspaper Glas naroda and became its editor-in-chief in 1916; he held this position until his death (Bajec).

19 Zgaga, Peter. "Mark Twain." Glas naroda, 2/12/1935, p. 2. The original version of the poem is available online: https://warprayer.org/ 
his own works and those by other authors (for instance, he published the Personal Memoirs of Ulysses $S$. Grant), that he eventually had to declare bankruptcy, but by giving public performances and by writing more works, he regained his fortune. The anonymous author of the article concludes on a bitter note, claiming that Twain could not have accomplished so much if he had been Slovenian, since "it was better to sweep the streets than to write in Slovenian"20. A post-war article entitled "The Path to a Socialist Society" $(27 / 1 / 1921,3)$ references the novel The Gilded Age, which Twain co-authored with Charles Dudley Warner. ${ }^{21}$ A note accompanying the translation of the short story "Lionizing Murderers" (26/7/1928, 5) states that Twain ridiculed high society and that he completely saw through the mentality of the American people, whom he thrashed with his vicious satire. Furthermore, the anonymous author of the text proclaims the contemporary general public to be no different from that of Twain's era. ${ }^{22}$

Over the decades, Twain was perhaps featured most prominently in Prosveta, a newspaper that also had clear socialist leanings. In an article on his life $(1 / 2 / 1927$, 4), it is noted that in his later works, Twain wrote satires about Christianity, and it is asserted that in his humour there is something serious and ethical; furthermore, his works are compared to those of two other giants of world literature: the anonymous author of the article claims that deep down Twain was melancholic like Cervantes and that, like Molière, he abhorred mendacity, dishonesty and hypocrisy. ${ }^{23}$ An author with the initials Fr. B. accompanies a few anecdotes about Twain $(19 / 8 / 1929,3)$ with a biographical note describing him as an "always laughing jovial fellow, who only sees the funny side of life and who can instantly infuse the most serious things with a portion of humour, grotesque and comicality". ${ }^{24}$ An anonymous article $(13 / 12 / 1935,2)$ published after the centennial of Twain's birth criticizes American society for allegedly seeing him only as a great humorist, but suppressing the real Twain: a freethinker and friend to organized workers. ${ }^{25}$ Another anonymous article $(27 / 11 / 1935,4)$ claims that Twain is the greatest American humorist, who made a name for himself with his unsurpassed satire. The article continues with the assertion that Twain was a harsh critic of organized religion - something which many of his biographers tend to either cri-

20 N.N. “Delavstvo ima rešitev samo v sebi." Proletarec, 17/4/1917, p. 4.

21 N.N. "Koraki v socialistično družbo." Proletarec, 27/1/1921, pp. 2-3.

22 N.N. Poveličavanje morilcev.” Proletarec, 26/7/1928, pp. 5-6.

23 N.N. "Mark Twain." Prosveta, 1/2/1927, p. 4.

24 Fr. B. "Par ameriških humoresk." Prosveta, 19/8/1929, p. 3. The same article had been previously published on Slovenian territory, i.e. in: N.N. "Par ameriških humoresk." Življenje in svet, 2/8/1929, pp. 128-29.

N.N. “Dr. Breasted bo živel.” Prosveta, 13/12/1935, p. 2. 
tique or withhold from the public. Additionally, this article states that America embraced Twain the humorist, but overlooked Twain the freethinker; his views on religion are illustrated by quoting a slightly adapted passage from The Mysterious Stranger, which in the original reads as follows: ${ }^{26}$

[...] God who could make good children as easily as bad, yet preferred to make bad ones; who could have made every one of them happy, yet never made a single happy one; [...] who created man without invitation, then tries to shuffle the responsibility for man's acts upon man, instead of honorably placing it where it belongs, upon himself; and finally, with altogether divine obtuseness, invites this poor, abused slave to worship him! (n.p.)

Ivan Molek $^{27}(3 / 11 / 1937,4)$ reports that Twain's The Adventures of Tom Sawyer has been recently banned in Brazil because the censor there deemed the novel to be communist propaganda. ${ }^{28}$ The author of the article ridicules this, stating that Twain was not even aware of the existence of communism or Bolshevism, but that indeed he was a freethinker and was highly critical of Russian tsarism, as well as opposed to slavery, tyranny and superstition. Molek goes on to assert that in totalitarian states and in those leaning towards totalitarianism, anybody in favour of true democracy and free thought is labelled a communist..$^{29}$ In a notable post-war article $(15 / 12 / 1947,3)$, a writer under the pseudonym of ALPA prefaces an indepth review of the recently published translation of The Adventures of Tom Sawyer by stating the following about Twain:

He was resented because of what he said and wrote. The bureaucratic moralizers representing the American public opinion sensed that he was a person with an unadapted mind of his own. That is to say that as a young man Twain did not have the desire to become part of the petty bourgeoisie, which was sustained by money, philistinism and false authority. [...] Twain is regarded as one of the world's greatest humorists. His irony only seldom falls into the realm of sarcasm, and his humour nowadays seems innocent, covered by a thin layer of romantic realism. However, his lying moral contemporaries rightly reproached him with a revolutionary tendency, which threatened to destroy the 'solid' American mentality built upon the patrician petty bourgeoisie, global trade and the Dollar.

26 N.N. "Mark Twain." Prosveta, 27/11/1935, p. 4.

27 Ivan Molek (1882-1962) was a writer and publicist, who immigrated to the United States in 1900. He published articles in many left-wing Slovenian serial publications, and served as the editor-in-chief of the newspapers Proletarec and Prosveta. His writing had a clear ideological agenda: promoting Marxism (Pirjevec).

28 This is later also reported in Cankarjer glasnik (71).

29 Molek, Ivan. "Malo tega in onega." Prosveta, 3/11/1937, p. 4. 
The reviewer then goes on to describe and interpret the plot of the novel, claiming that Twain intended to expose the education system of the provincial petty bourgeoisie, as well as to ridicule the values of the capitalist system. Furthermore, ALPA praises the translation, but criticizes the illustrations, which he or she deems way too comical for a text that is critical of society. ${ }^{30}$

The monthly Mladinski list also published a few lengthy articles on Twain (written in English), for instance one entitled "How Mark Twain Wrote Huckelberry [sic] Finn” by American journalist and author James O'Donnell Bennett (15051). In another notable article entitled "Some Authors You Should Know", an anonymous author claims that Twain never reached his full artistic potential because he was held back by his wife and daughters-the following critical account of the writer is given:

America does not honor thinkers, philosophers, or at least it didn't in Twain's day. So the heavy-hearted man hid under a shell of humor. Only occasionally did he break through and "turn himself loose," but when he did he produced work that will last as long as the English language is written. He wrote many volumes, but most of them will be forgotten at a time when every boy and man, too, is still reading "Huckleberry Finn" and thousands of others, in their study of this strange, sad man, will read his bitterly satirical "What is Man" and "The Mysterious Stranger." [...] God only knows how much Twain might have enriched American literature if he had not been a coward, afraid of his wife, afraid of the disapproval of his neighbors, afraid to "be himself." [...] If he could only have been free to write what he wanted, we say! Well, perhaps, "Huckleberry Finn" is enough to ask of any man. By all means, every child should read it. There are still libraries that are "simply too nice" to permit it on their shelves, but the book is widely printed and can be procured everywhere. (280)

Another notable article in the same magazine states that Twain participated in the Civil War on the Confederate side, but later felt guilty for having fought to uphold slavery and tried to make up for it by being benevolent towards black people and even paying the tuition for a black student at Yale University. The article relates that, as a young man, Twain joined the printer's union, that he understood the workers' point of view and was in favour of unionization throughout his life. The following is also stated:

His friend, William Dean [Howells] said, "His mind and soul were with those who do the hard work of the world in fear of those who give them a chance for their livelihoods and underpay them all they can ... He saw ... THAT IN THE UNION WAS THE WORKINGMAN'S ONLY HOPE OF STANDING

30 ALPA. "Pustolovščine Toma Sawyera [sic]." Prosveta, 15/12/1947, p. 3. 
UP LIKE A MAN AGAINST MONEY AND THE POWER OF IT .”[...] In all of his works, Mark Twain preached the equality of man and democracy. Even in those books that were considered entirely humorous, there was much beneath the surface to make the reader think. [...] Mark Twain was one of those great men who live once in every era of human history, it seems. (7; capitalization in the original newspaper article) $)^{31}$

Furthermore, in an article entitled 'Youth and Democracy', Mladinski list's editor-in-chief Ivan Molek hails Twain as the greatest American satirist and humorist, as well as a great democrat, freethinker and humanitarian, who should be seen as a role-model by Slovenian-American youth (4).

Although many Slovenian newspapers continued to exist after the end of World War II, Twain is rarely mentioned, and if he is, political sentiments are expressed even less frequently. Ameriška domovina (26/4/1946, 6), for instance, states that "Tom Sawyer and Huckleberry Finn are American traditions, as American as apple pie or corn bread" 32 . In Zarja the following is written: "His typical boys' stories made him very famous. Among his masterpieces are the adventures of Tom Sawyer and Huckleberry Finn, which are enjoyed by young and old alike" (349). In Enakopravnost $(21 / 2 / 1949,2)$, it is mentioned that a Slovenian translation of Adventures of Huckleberry Finn has been published, ${ }^{33}$ another article in the same newspaper (16/6/1949,2) compares this novel and The Adventures of Tom Sawyer to Howard Fast's novel Citizen Tom Paine (which also criticizes society), ${ }^{34}$ while in a later article in Enakopravnost (14/11/1956,2), Twain's hometown of Hannibal is described as a bigger tourist attraction than Hawaii. ${ }^{35}$

\section{CONCLUSION}

The analysis showed the many different stages in the 'historical life' of Mark Twain and his works among Slovenian immigrants in the United States. While the articles published during Twain's lifetime almost exclusively reported on the events in his life, his posthumous reception was heavily influenced by the ideological orientation of the serial publication in which Twain and/or his works were discussed.

31 For the context of the quoted passage, see Howells (38).

32 N.N. "St. Mary's Day." Ameriška domovina, 26/4/1946, p. 6.

33 N.N. "Slovenska knjiga v letu 1948." Enakopravnost, 21/2/1949, p. 2.

34 Željeznov, Dušan. “Fastov Tom Paine.” Enakopravnost, 16/6/1949, p. 2. This article had been previously published on Slovenian territory, i.e. in: Željeznov, Dušan. "Fastov Tom Paine.” Slovenski poročevalec, 15/5/1949, p. 3. Dušan Željeznov (1927-1995) was a publicist and translator who wrote extensively about literature and translated several works from Russian and Italian (Pibernik).

N.N. “Mark Twainov Hannibal, Missouri." Enakopravnost, 14/11/1956, p. 2. 
Although on a few occasions the same article was published in both conservative and liberal newspapers, as early as World War I, for instance, Twain's image was used to express support for the Austro-Hungarian Empire in the Catholic newspaper Glasilo K.S.K. jednote and to strongly condemn the Central Powers in the left-wing newspaper Glas naroda.

In right-leaning publications, Twain was seldom discussed and was primarily presented as a great and commercially successful humorist. He was featured significantly more frequently and discussed with more depth in left-leaning publications, where he was presented, above all, as a progressive advocate for social justice / social critic, who condemned capitalist and imperialist exploitation, racism, elitism, organized religion, etc. This is true especially for the magazine Mladinski list and the newspapers Proletarec and Prosveta, in all of which several articles about Twain have a clear socialist agenda.

After the Second Red Scare began in 1947 and especially after the onset of McCarthyism in 1950, articles about Twain began to be published far less often and for the most part had no clear ideological agenda, since during that time it was dangerous to express sentiments that could be interpreted as socialist or communist in sympathy. The fact that this is the case even for Slovenian immigrant serial publications, which were published in a foreign language and had limited circulation, is a good example of how the contemporary political situation in the United States substantially influenced the reception of certain literary works and their authors.

\section{WORKS CITED}

Arac, Jonathan. "Preface." Huckleberry Finn as Idol and Target. Edited by Jonathan Arac. Madison, WI: The University of Wisconsin Press, 1997, pp. vii-ix.

Baldick, Chris. The Concise Oxford Dictionary of Literary Terms, 2nd Edition. Oxford/New York: Oxford University Press, 2001.

Bajec, Jože. “Trček, Janez (1891-1942).” Slovenska biografija. Slovenska akademija znanosti in umetnosti, Znanstvenoraziskovalni center SAZU, 2013. http:// www.slovenska-biografija.si/oseba/sbi719126/\#slovenski-biografski-leksikon (Accessed 15 June 2019).

Brooks, Van Wyck. The Ordeal of Mark Twain. New York: E.P.Dutton \& Company, 1920.

Cowley, Malcolm. "Malcolm Cowley, New Republic." Ernest Hemingway: The Critical Heritage. Edited by Jeffrey Meyers. London/Nerw York: Routledge, 2005, pp. 180-82.

Culler, Jonathan. Literary Theory: A Very Short Introduction. Oxford: Oxford University Press, 2000. 
Gustafson, Sandra M. "Democratic Fictions." A Companion to American Fiction 1780-1865. Edited by Shirley Samuels. Malden/Oxford/Carlton: Blackwell Publishing, 2004, pp. 31-39.

Grosman, Meta. Knjižeonost v medkulturnem položaju. Ljubljana: Znanstveni inštitut Filozofske fakultete, 2004.

Howells, William Dean. My Mark Twain: Reminiscences and Criticisms. Edited by Marilyn Austin Baldwin. Louisiana: Louisiana State University Press, 1999.

Jauss, Hans Robert. "Literary History as a Challenge to Literary Theory." Translated by Elizabeth Benzinger. New Literary History vol. 2, no. 1, 1970, pp. 7-37.

Jauss, Hans Robert. Estetsko izkustvo in literarna hermenevtika. Translated by Tomo Virk. Ljubljana: Literarno-umetniško društvo Literatura, 1998.

Krieg, Joann P. "Literary Contemporaries." A Companion to Walt Whitman. Edited by Donald D. Kummings. Malden/Oxford/Carlton: Blackwell Publishing, 2006, pp. 392-408.

Lamb, Robert Paul. "America Can Break Your Heart: On the Significance of Mark Twain." A Companion to American Fiction 1865-1914. Edited by Robert Lamb and G. R. Thompson. Malden/Oxford/ Carlton: Blackwell Publishing, 2005, pp. 468-98.

Messent, Peter. The Cambridge Introduction to Mark Twain. Cambridge: Cambridge University Press, 2007.

Molek, Ivan. "Mladina in demokracija." Mladinski list, vol. 19, no. 10, 1940, p. 4.

N.N. "Some Authors You Should Know." Mladinski list, vol. 16, no. 9, 1937, p. 280.

N.N. “Cenzura." Cankarjer glasnik, vol. 2, no. 3, 1938, pp. 70-71.

N.N. "Mark Twain." Mladinski list, vol. 17, no. 11, 1938, p. 7.

N.N. "Mark Twain.” Zarja, vol. 18, no. 11, 1946, p. 349.

O’Donnell Bennett, James. "How Mark Twain Wrote Huckelberry [sic] Finn." Mladinski list, vol. 9, no. 5, 1930, pp. 150-51.

Pezdirc Bartol, Mateja. "Vloga bralca v poglavitnih literarnoteoretičnih smereh 20. stoletja [I. del]." Jezik in slovstvo vol. 45, no. 5, 2000, pp. 195-206. https:// www.dlib.si/details/URN:NBN:SI:DOC-KRUPXH0A (Accessed 30 May 2019).

Pibernik, France. “Željeznov, Dušan (1927-1995).” Slovenska biografija. Slovenska akademija znanosti in umetnosti, Znanstvenoraziskovalni center SAZU, 2013. http://www.slovenska-biografija.si/oseba/sbi896321/\#slovenski-biografski-leksikon (Accessed 15 June 2019).

Pirjevec, Avgust. "Molek, Ivan (1882-1962)." Slovenska biografija. Slovenska akademija znanosti in umetnosti, Znanstvenoraziskovalni center SAZU, 2013. http://www.slovenska-biografija.si/oseba/sbi374601/\#slovenski-biografski-leksikon (Accessed 15 June 2019). 
Twain, Mark. Mark Twain's Notebook. Edited by Albert Bigelow Paine. New York/ London: Harper \& Brothers, 1935.

Twain, Mark. The Mysterious Stranger. Project Gutenberg, 2006. http://www. gutenberg.org/files/3186/3186-h/3186-h.htm (Accessed 11 February 2019).

Twain, Mark. Autobiography of Mark Twain, Volume 2: The Complete and Authoritative Edition. Edited by Benjamin Griffin and Harriet E. Smith. Berkeley: University of California Press, 2013.

Zupan, Simon. "Recepcija slovenskih prevodov kratkih zgodb Edgarja Allana Poeja v 19. in 20. stoletju." Primerjalna knjižeronost vol. 38, no. 1, 2015, pp. 12144. https://www.dlib.si/details/URN:NBN:SI:doc-KF5XZAAX (Accessed 30 May 2019).

Janko Trupej

Laška vas 21, 3273 Jurklošter janko.trupej@gmail.com

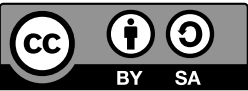

\section{Ideološki vplivi na recepcijo Marka Twaina med Slovenci na drugi strani Atlantika}

Članek obravnava recepcijo Marka Twaina in njegovih del v serijskih publikacijah slovenskih priseljencev v Združenih državah Amerike. Analiza je zajemala zapise, objavljene $\mathrm{v}$ časopisih in revijah $\mathrm{z}$ različnimi ideološkimi usmeritvami od začetka do sredine 20 . stoletja. Članek primerja Twainovo recepcijo v levo usmerjenih in desno usmerjenih publikacijah ter obravnava tudi vprašanje, $v$ kolikšni meri so na recepcijo vplivale sodobne politične razmere $\mathrm{v} Z \mathrm{DA}$.

Ključne besede: Mark Twain, recepcija, serijske publikacije, ideologija, Slovenci v ZDA, ameriška književnost 